\title{
The Responsibility for Forest Research ${ }^{1}$
}

\author{
Gilbert Paillé ${ }^{2}$
}

\section{Introduction}

Hereafter, the general public, researchers and their employers are considered to be responsible for forest research in Canada. Some statistics are discussed in view of comparing the relative performance of industry, government and university. A common goal is suggested as the best way of improving the present and future situation.

\section{Public Responsibility}

First of all, I think that forest research is an economic activity and that the ultimate responsibility for any economic activity must be taken by those who pay the bill. Thus, the Canadian public must be responsible for forest research because it is supporting this activity through the purchase of forest goods and services, and through taxation.

The Canadian public is also responsible for demanding forest research. Up until recently, there has not been much of it done in Canada partly because the public was not well informed of the refinements of the methods we used to administer, protect, exploit and utilize our abundant and wild forest resources. However, the trend has been shifting slowly as better communication methods were developed, and as more and more people go to the woods to work or recreate. When they realized, for example, that the forests were sprayed with chemical insecticides, they said: "find something else". When they realized that the current method for harvesting forest stands was by extensive clearcuts, when they appreciated the incomplete use of forest biomass, or the lack of forest regeneration, or the expensiveness of many traditional wood products, they told researchers to find better methods.

\section{Researchers' Responsibility}

Since the researchers are those who actually do the research, they thus have as a primary responsibility to inform the public correctly about the status and advancement of forestry in order to get the mandate and funds to find something different, better, or more acceptable to the Canadian society.

In the U.S., where many things happen before coming into Canada, national conferences on forest and research planning are being held where the public is invited to submit suggestions for research prộrams; last year, researchers thus received 3000 program suggestions in Washington D.C. (Dickerman, 1978). Computerized methods for evaluating public opinion about renewable resources have been tested, and research-needs-response approaches have been implemented (Anon. 1977a) to ensure that systems used by the forest service for managing forests and associated resources will best meet the needs of the people now and in the future.

We, however, still tend to resist public invasion into Canadian laboratories, or to demonstrate to those who dare raise their voices against our current ways of doing things, that they are wrong in their understanding of the complexities of forestry matters.

In short, my point is the following: the Canadian public is largely responsible for demanding and for funding forest

!Presented to Sylvicon 1979 in Fredericton, N.B., February 22, 1979

'Director, Woodlands Research, Canadian International Paper Company, Montreal research. Researchers have a tremendous opportunity for advancement and better recognition if they dare inform this public correctly on forestry matters, listen carefully to its comments and suggestions, and build proper mechanisms to adjust their programs when deemed necessary.

Forest researchers also have the responsibility to keep in close contact with forest managers because forest research is a tool of forest management and, as stated in the 1978 program of work of the Maritime Forest Research Centre, "technical information is of little value if it does not get put into practice by those responsible for management of the forest resource".

If such a statement sounds logical to everybody, one must be aware that it is not yet the currect practice everywhere. In 1976 Armson reported that a minority of management foresters (about 10\%) were conscious of their use of information or techniques directly attributable to the results of forest research in Ontario. It was more the other way around; they believed that research had rather provided a documentation of techniques innovated by field management foresters.

Thus, researchers must make a special effort to get personally closer to the stumps where they can learn from those currently running the forest show what are the major problems to be solved, and tell them what are the solutions that have been found so far. This is a heavy responsibility.

\section{Employers' Responsibility}

Now, there is not much that researchers can do to improve the situation along those lines if their employers are not properly equipped to support a meaningful research and development activity. Let us have a quick look at the current R\&D activity supported by the three major groups of employers, in their respective order of present financial involvement, and let us see how they take their responsibilities.

The Private Enterprise: The private enterprise is responsible for research because each firm must continuously call upon innovation to solve development problems, and upon improvement of productivity to keep ahead of competition and stay in business.

According to the Canadian Ministry of State for Science and Technology (Anon. 1978a), private enterprises in most industrialized countries of the world are funding 40 to $50 \%$ of the R\&D work done in all sectors of the economy, and are executing between 50 and $65 \%$ of it; R\&D budgets represent more than $2 \%$ of the gross national product (GNP).

In Canada, the private sector provided $35 \%$ of the R\&D money in 1977 , and executed $44 \%$ of the research; its share has been increasing steadily for the last 15 years. However, total expenses on R\&D represented $\$ 2$ billion or only $1 \%$ of the GNP; when expressed in constant dollars, this effort on R\&D did not increase during the last 10 years.

This situation, considered to be critical, has prompted the Ministry of State to put forward a new policy and concrete measures in 1978 for enhancing industrial research. I suggest that the Canadian forest industry should take all the advantages possible of this new policy. Even if it is spending more on research at the present time than both levels of government, its contribution of approximately $\$ 65$ million a year does not represent $0.5 \%$ of the value of production and it amounts to only $3 \%$ of the total R\&D effort in Canada (Table 1). 
A closer look at this budget reveals that more than $85 \%$ of the funds are allocated to forest products research of which $\$ 3$ out of $\$ 4$ are spent on pulp and paper problems by a few companies (Smith 1978). This leaves little money for solid wood products research and for woodlands research.

In the solid wood products, most of the 8000 firms (Anon. 1978 b and Mathur 1978) are individually too small to afford viable research units, and the diversity of their production is such that research needs are tremendously variable. They currently rely on government to satisfy a large portion of them.

In woodlands activities, one must consider the varying degrees of responsibilities for forest management that are given to industry by the provincial governments before judging performance. As suggested by Reed in his latest report (Reed 1978), the nature of the tenure, the regulations of the province, and the extent to which the Crown participates in the cost of forest management are important criteria influencing industry participation.

It is important to note here that the best examples of industrial activity in woodlands research and development have so far been observed more frequently within companies having sizable private lands and Canadian ownership. However, for some years now, a certain level of competition in woodlands R\&D has been developing amongst some companies regardless of ownership or land tenure; it has to do more now with social responsibilities, public image, and future availability of fibre supply. This trend should be enhanced through more confidence placed on industrial capability, and better sharing of responsibilities for intensive forest management between government and industry.

The Government. Now, let us have a look at the government performance in forest research. It is important to note right here that the federal government is committed to forest research by legislation (Smith and Lessard 1971), and so are some provincial governments (Anon. 1977b).

For $1977-78$, the government contribution to forest research was $\$ 44$ million (Table 1 ) and its revenues from the forest sector were $\$ 1.7$ billion (Reed 1977); this means that the investment in research was $2-1 / 2$ cents per dollar of revenue. To this, one can add 5-1/2 cents for forest renewal, and 20 cents for all other forest management activities.

These statistics tell us that forest research and forest management still do not have a high priority on parliament hill. This is one major reason why I suggested that the Canadian public should in priority be better informed, hoping that the government would then be pressed to improve its perfor-

Table 1. Approximate forest research expenses in Canada. 1977-1978.

\begin{tabular}{llc}
\hline Agency & & $\begin{array}{c}\text { Million } \\
\text { dollars }\end{array}$ \\
\hline Industry & PPRIC & 7 \\
& FERIC & 2 \\
& In-House & \\
& $\quad$ Forest products & 50 \\
Government & $\quad$ Woodlands & $5-25$ \\
Federal & National Institutes & \\
& Forest products labs & 7 \\
Provincial & Forest research centres & 20 \\
& B.C. & 2.8 \\
& Quebec & 2 \\
& Ontario & 0.8 \\
& Others & 0.9 \\
University & Faculties of forestry & 2 \\
& Other faculties & $?$ \\
\hline
\end{tabular}

mance. The information process is already under way in most research centres, and it takes the form of public information projects or public information services; what seems to be missing in many cases is an information-feedback-appreciation mechanism.

The statistics also tell us that, at least before the $\$ 5$ million cut-back in research spending announced recently and the privatization of the forest products laboratories, the federal government was putting into forest research a share of its total expenditures 20 times larger than that of provincial governments. At this time, and account being taken of the provincial responsibilities in the forest sector, substantial increases in provincial activities would certainly have been better news than partial cuts in the federal budgets. As for the privatization of forest products laboratories, it should be considered as a logical step if it has the main consequence of bringing researchers still closer to wood users.

The University. Finally, our six forestry faculties are responsible for preparing foresters and researchers, and for doing research. But, it is only during the last 16 years or so that they have been really able to generate a significant number of researchers and to undertake some research programs.

At the moment it is believed that the post-graduate programs in forestry cannot meet the need for forest scientists in the country. One of the reasons might be that several recommendations included in the Garratt Report (Garratt 1971) have not yet been fully implemented, in particular those pertaining to the cooperation with non-university agencies, and the recruitment procedures.

Another reason might be that the number of undergraduate students has increased exponentially in the last 15 years together with teaching loads; this may have prevented many forestry professors from undertaking enough sustained and meaningful research activity to attract sufficient interest from potential graduate students and funding agencies.

This year research funds allocated from all sources to our six Canadian forestry schools should be less than $\$ 2$ million, of which about half should come from the federal government. My understanding is that more funds are now available from the federal government to support forestry related projects outside the forestry faculties than inside; moreover, all the money available from the federal government for university forestry research represents only approximately $1 \%$ of the Canadian total.

\section{Joint Responsibility}

From this rapid overview of the present situation, one might conclude that since no one organization has been able so far to attract enough attention and funds to really give forestry research the place it should have, the thing to do would be to consider it, from now on, as a joint responsibility.

However, many trials have been made already along those lines, and many more have been suggested. In the U.S., for example, the Pinchot Institute (Anon. 1973) has been advocating a consortium for environmental studies to bring together interested universities and the Forest Service for the solution of environmental forestry-research problems. In Canada, Forest Research Boards, Councils, Joint Committees and Co-operatives have been created (and many still operate) to define priorities and plans, in order to avoid duplication and improve the coordination between researchers of all provenances. The creation of an independant research institute supported by both levels of government, the universities and industry has even been suggested (Armson 1976).

I believe that, whatever responsibility each partner is ready to promote and whatever responsibility each partner is ready to assume, the result will not be satisfactory unless all partners have a common goal, which could be the one in- 
cluded within the policy announced in 1978 by the Canadian Ministry of State, Science and Technology (Anon. 1978a) and which reads as follows:

\begin{abstract}
"Give increased emphasis to the need for technology transfer to industry as an objective of all governmental research activities; and to establish institutions and to reinforce other mechanisms for the transfer of ideas, innovations, information, skills, man power, and technical capacity from government to industry and from universities to industry".
\end{abstract}

If this has to be done in all sectors of the economy, why could it not be done first in forestry?

\section{Conclusion}

I suggested at the beginning that everybody in Canada should be responsible for forest research. If we add up a few thousand researchers and forest managers, the Board of Directors of some 10000 forest enterprises, eleven Ministers of Natural Resources and civil servants in forestry, more than 2000 forestry students, 1000000 persons directly or indirectly employed in the forest sector, their families, plus conservationists, recreationists and journalists, the total should not be far from 20 million.

If we add up annual expenses for forest research of $\$ 65$ million by industry, $\$ 44$ million by governments and $\$ 2$ million by universities, it represents only $\$ 5$ per Canadian; no wonder that forestry is now being considered as an area of national concern. However, judging by the interest that foresters are currently devoting to that problem, I am confident that this situation will not remain unchanged for very long, especially if they manage to let the Canadian public know about it.

\section{References}

Anon, 1973. The Pinchot Institute system for environmental forestry studies. U.S.D.A. Technical Report NE-2.

Anon, 1977a. The research-needs-response program in the intermountain West. U.S.D.A. Forest Service.

Anon, 1977b. Lois concernant les terres et forêts publiques. Ministère des Terres et Forêts, Editeur Officiel du Québec.

Anon, 1978a. Measures to strengthen and encourage research and development in Canada. Policy Announcement. Ministry of State, Science and Technology, Canada.

Anon, 1978b. La recherche sur les produits forestiers - question d'intérêt public. Forêt Conservation 45(3): 24-26.

Armson, K. A. 1976. Forest management in Ontario. Ministry of Natural Resources, Ontario.

Dickerman, M. B. 1978. National conference on forest and rangeland research planning. J. For. 76(5): 296-97.

Garratt, G. A. 1971. Forestry education in Canada. C.I.F.

Mathur, V.N.P. 1978. R\&D in solid wood products. Environment Canada, Forestry Service, Inf. Rep. DPC-X-7.

Reed, F.L.C. \& Assoc. 1978. Forest management expenditures in Canada compared to taxes generated by the forest sector. Prepared for CPPA. Vancouver.

Smith, J. H. G., and G. Lessard. 1971. La recherche forestière au Canada. Etude de documentation pour le Conseil des Sciences du Canada; étude spéciale No 14.

Smith, J. H. G. 1978. Forest Resources Research in Canada. J. For. 76(9): 566-70.

\section{EDWARD}

\section{FELLOWS}

FORESTRY \& FOREST PRODUCTS CONSULTANT

P.O. Box 354, 404 Queen St.,

FREDERICTON, N. B.

Registered Professional

Forester (N. B.)

MEMBER:

Canadian Institute of Forestry

Forest Products Research

Society, Etc.

INDUSTRY DEVELOPMENT - FOREST PRODUCTS ECONOMIC FOREST POLICY \& ADMINISTRATION

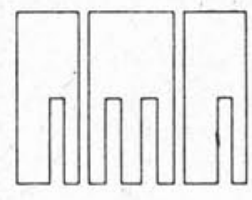

\section{Alan Moss \& Associates Ltd.}

Consultants in Forestry and Forest Industries

\section{Domestic and International}

\author{
1334 St. Paul Street
}

Kelowna, British Columbia V1Y 2E1

Telephone: (604) 763-4811

Cable: Sylva

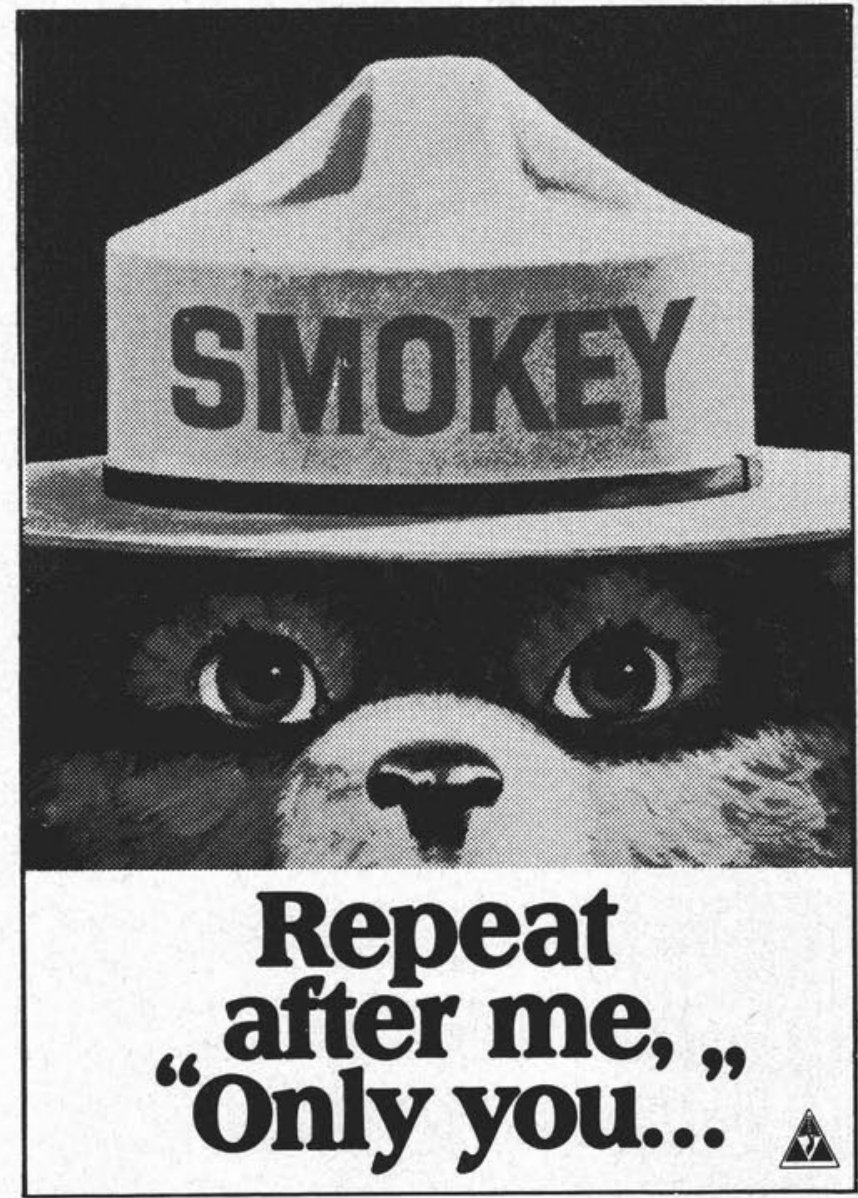

